Bond University

Research Repository

\title{
The ghost of rankings past: The lasting harmful impact of journal rankings, and what we should do instead
}

Svantesson, Dan Jerker B; Corkery, James; McCabe, Bernard

\section{Published in:}

Bond Law Review

\section{Licence:}

CC BY-NC-ND

Link to output in Bond University research repository.

Recommended citation(APA):

Svantesson, D. J. B., Corkery, J., \& McCabe, B. (2014). The ghost of rankings past: The lasting harmful impact of journal rankings, and what we should do instead. Bond Law Review, 26(2), 71-85.

https://blr.scholasticahq.com/article/5624

\section{General rights}

Copyright and moral rights for the publications made accessible in the public portal are retained by the authors and/or other copyright owners and it is a condition of accessing publications that users recognise and abide by the legal requirements associated with these rights.

For more information, or if you believe that this document breaches copyright, please contact the Bond University research repository coordinator. 


\section{Bond Law Review}

Volume 26 | Issue 2

Article 5

2014

The ghost of rankings past - The lasting harmful impact of journal rankings, and what we should do instead

Dan Svantesson

Jim Corkery

Bernard McCabe

Follow this and additional works at: http://epublications.bond.edu.au/blr

This Article is brought to you by the Faculty of Law at ePublications@bond. It has been accepted for inclusion in Bond Law Review by an authorized administrator of ePublications@bond. For more information, please contact Bond University's Repository Coordinator. 


\title{
The ghost of rankings past - The lasting harmful impact of journal rankings, and what we should do instead
}

\begin{abstract}
A journal ranking exercise took place in 2008-2010. It tried to produce a journal ranking list with international scope and validity. It failed.

The urge to rank — and to use ranking in the assessment of quality — appears to remain strong in Australian law schools. There is a risk this discredited process will be given new impetus by the latest Australian journal ranking list involving law, this time by the Australian Business Deans Council. Its list ranks 2,767 different journal titles, including selected law journals.

The authors believe rankings like these should be formally abandoned for a number of reasons. First, the ranking process is difficult, arbitrary and infected by subjective opinion. This leads to perverse outcomes for legal academics whose career advancement is tied to this uncertain standard. Secondly, the urge to rank is the product of a damaging misconception of the proper role of legal academics and the legal academy. Finally, in the brave new educational world, markets will provide surprisingly nuanced and rigorous measures of quality that cannot be captured in a crude ranking.
\end{abstract}

\section{Keywords}

Law journal rankings, journal rankings, legal scholarship, quality of scholarship 


\title{
THE GHOST OF RANKINGS PAST - THE LASTING HARMFUL IMPACT OF JOURNAL RANKINGS, AND WHAT WE SHOULD DO INSTEAD
}

\author{
DAN JERKER B. SVANTESSON* ${ }^{*}$ JIM CORKERY** AND BERNARD MCCABE***
}

\begin{abstract}
A journal ranking exercise took place in 2008-2010. It tried to produce a journal ranking list with international scope and validity. It failed.

The urge to rank - and to use ranking in the assessment of quality - appears to remain strong in Australian law schools. There is a risk this discredited process will be given new impetus by the latest Australian journal ranking list involving law, this time by the Australian Business Deans Council. Its list ranks 2,767 different journal titles, including selected law journals.

The authors believe rankings like these should be formally abandoned for a number of reasons. First, the ranking process is difficult, arbitrary and infected by subjective opinion. This leads to perverse outcomes for legal academics whose career advancement is tied to this uncertain standard. Secondly, the urge to rank is the product of a damaging misconception of the proper role of legal academics and the legal academy. Finally, in the brave new educational world, markets will provide surprisingly nuanced and rigorous measures of quality that cannot be captured in a crude ranking.
\end{abstract}

\section{INTRODUCTION}

Many Australian law academics were appalled by the journal ranking exercise that took place in 2008-2010 (the 'CALD $1 /$ ERA $^{2}$ ranking'). The aim then was to produce a journal ranking list with international scope and validity. ${ }^{3}$ Unsurprisingly, this grandiose result was not achieved and the process was abandoned in 2011 - but not

* Professor and Co-Director, Centre for Commercial Law, Faculty of Law, Bond University. Researcher, Swedish Law \& Informatics Research Institute, Stockholm University.

** Professor and Co-Director, Centre for Commercial Law, Faculty of Law, Bond University.

*** Deputy-Director, Centre for Commercial Law, Faculty of Law, Bond University.

1 Council of Australian Law Deans.

2 Excellence in Research for Australia.

3 See Dan Svantesson and Paul White, 'Entering an era of research ranking - Will innovation and diversity survive?' (2009) 21(3) Bond Law Review 173, 191. 
before damage was done. The then Minister for Innovation, Industry, Science and Research (Senator Kim Carr) noted that there

is clear and consistent evidence that the rankings were being deployed inappropriately within some quarters of the sector, in ways that could produce harmful outcomes, and based on a poor understanding of the actual role of the rankings. One common example was the setting of targets for publication in $\mathrm{A}$ and $\mathrm{A}^{*}$ journals by institutional research managers. ${ }^{4}$

The urge to rank - and to use ranking in the assessment of quality - lingers in Australian universities, and journal ranking remains on the agenda also in law schools. ${ }^{5}$ There is a risk this discredited process will be given new impetus following the release of the latest Australian journal ranking list involving law, this time by the Australian Business Deans Council ('ABDC'). The ABDC describes itself as 'the authoritative and collective voice of pro vice-chancellors, executive deans and heads of all 40 business faculties and schools in Australia'.6 Its list ranks 2,767 different journal titles, including selected law journals. The ranking method used involved 'public submissions, qualitative and quantitative data assessment, public exposure feedback and international expert consultation'.7

As pointed out by van Gestel, '[r]anking is ... a low-cost, low-benefit method of evaluation - cheap, but crude', ${ }^{8}$ and rankings like these should be formally abandoned for two reasons. First, as the CALD/ERA process demonstrated, the ranking process is practically difficult. It is arbitrary and infected by subjective opinion. This leads to perverse outcomes for legal academics whose career

4 Senator Kim Carr, 'Ministerial Statement to the Senate Economics Legislation Committee Improvements to Excellence in Research for Australia (ERA)' (Media Statement, 30 May 2011) 2 <http://www.arc.gov.au/media/releases/Ministerial_releases/2011_05_30_ministerial $\% 20$ statement.pdf $>$.

5 For example, at a meeting in November 2014 the Council of Australian Law Deans agreed that a journal list for the discipline of law would be a helpful resource. See University of Wollongong Australia, UOW Hosts Council of Australian Law Deans (CALD) (November 2014) Council of Australian Law Deans <http://lha.uow.edu.au/law/newsevents/UOW183402.html>.

6 Michael Powell, President's Welcome (2015) Australian Business Deans Council $<$ http://www.abdc.edu.au/pages/presidents-welcome.html $>$.

7 Australian Business Deans Council, ‘Journal Quality List 2013 Review' (Final Overall Report, November 2013), 3, 19 <http://www.abdc.edu.au/data/journal_review2013/Final_ Overall_Review_Panel_Report_Public_Exposure_Period_Nov_2013.pdf $>$.

8 Rob van Gestel, 'Sense and non-sense of a European Ranking of Law Schools and Law Journals' (2015) 35(1) Legal Studies 165, 185. 
advancement is tied to this uncertain standard. Secondly, the urge to rank is the product of a damaging misconception of the proper role of legal academics and the legal academy. The rankers appear to see law as another social science rather than a professional discipline. Fortuitously, rankings will be rendered redundant by any decision to deregulate fees. In the brave new world, markets will provide surprisingly nuanced and rigorous measures of quality that cannot be captured in a crude ranking.

\section{THE PRACTICAL OBSTACLES TO RANKING JOURNALS}

Legal scholarship has traditionally been found in a number of places. The primary source of scholarship in the common law lies in the reported judgments of the courts. It is also found in the reports of commissions and specialist bodies like the Australian Law Reform Commission and the Corporations and Markets Advisory Committee. In the academy, scholarship was traditionally found in textbooks and seminal articles especially those routinely accessed by judges, practitioners and law reformers, where it might contribute to the evolution of the law. ${ }^{9}$ But good scholarship is notoriously hard to define with precision, much less quantify. This last point - the difficulty of quantifying good scholarship - is particularly important. As noted by van Gestel, 'rankings always focus on quantifiable parameters. There are, however, many features of legal scholarship and education that are difficult to quantify, such as: "originality", "creativity" or "serendipity"'.10

Further, the true importance of scholarship might only become apparent over time, and it often springs from unusual places. Ideas and analyses that hold little appeal on their face might unexpectedly find favour in the hands of a skilled advocate. ${ }^{11}$ Scholarship, in short, is a fluid concept.

The Australian law deans effectively outsourced responsibility for (the arguably impossible task of) defining and measuring scholarship to those who rank law journals. In doing so, the deans invited the academic community to form a view about the quality of scholarship using a proxy: if the work is published in a journal

9 Many of our most influential and most cited law texts were written by scholar practitioners: see Meagher, Gummow and Lehane on Equity, or Heydon on Evidence.

10 Many of our most influential and most cited law texts were written by scholar practitioners: see J D Heydon, M J Leeming and P G Turner, Meagher, Gummow and Lehane's Equity: Doctrines \& Remedies (Lexis Nexis, 5th ed, 2014); J D Heydon, Cross on Evidence (Lexis Nexis, 10th ed, 2014).

11 By way of example, consider the insights of the legendary Mr Gambotto. His musings might be thought to have had little value (just ask Dyson Heydon and the NSW Court of Appeal) until he received an unexpectedly sympathetic hearing in the High Court. 
that enjoys a reputation for quality, the fact of publication is an independent endorsement of the quality of the work. This is a dangerous and corruptible notion. Further doubt is cast on this notion by the fact that a journal's reputation is often tied to the reputation of the law school, or indeed the university, to which it is attached. Thus, to a significant degree we are making judgements as to the quality of a particular article by reference to the reputation of the institution hosting the journal the article is published in. Given the logical distance between a particular institution's reputation and the articles published in a journal published by that institution, any perceived appeal of such an approach will quickly evaporate upon a soberminded consideration of the real state of things.

Leave to one side the fact that some of those journals are run by students who are even less well-placed than law deans to make judgments about the quality of scholarship. Ranking research and publication according to the host's repute says subliminally that excellent places beget excellent research. But is that really so?

There is no evidence that the dignity or repute of an institution turns up the juices of excellence. Science academics at the top-ranked Harvard or Oxford Universities produce no more excellence, judged by citation frequency, after they join Harvard or Oxford than before. The Economist reports that most

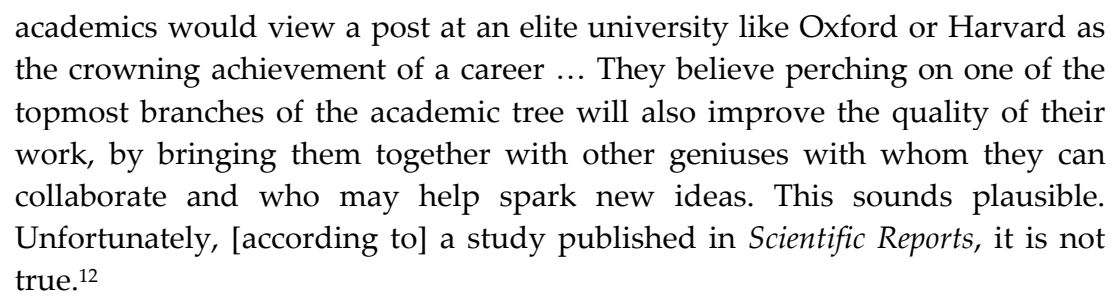
the crowning achievement of a career ... They believe perching on one of the topmost branches of the academic tree will also improve the quality of their work, by bringing them together with other geniuses with whom they can collaborate and who may help spark new ideas. This sounds plausible. Unfortunately, [according to] a study published in Scientific Reports, it is not true. $^{12}$

We will have more to say about alternative conceptions of quality in due course. But for now, consider the flaws in the ABDC ranking process that are likely to be present in all journal ranking efforts: ${ }^{13}$

- The journal ranking is incomplete, leaving out a vast number of journals in which members of business schools may wish to publish. This problem is all the more serious where there is no built-in system for constant addition of new or previously missed journals.

12 'Academic Prestige: Why Climb the Greasy Pole?', The Economist (online), 10 May 2014 $<$ http://www.economist.com/news/science-and-technology/21601811-getting-job-topuniversity-will-not-make-y o u - bet ter-resea r che r - w h y - cli m b $>$.

13 See Dan Svantesson, 'International Ranking of Law Journals - Can it be Done, and at What Cost?' (2009) 29(4) Legal Studies 678, 680. 
- Ranking exercises, even where based on statistics, cannot be objective. ${ }^{14}$

- The ranking represents a self-fulfilling prophecy as authors will target journals with high ranking regardless of how well regarded those journals were prior to the ranking exercise.

- It is not possible to compare generalist journals and specialist journals.

To this we must add an important observation made from the perspective of what should be the most central person - the reader. The fact is that the way we select what we read has changed. In the dark, pre-Internet past, a person deciding what to read was restricted by what was available in the library at hand. ${ }^{15}$ Because of limits in funds and/or shelf space, libraries needed to be selective as to which journals they bought in and this obviously favoured the established journals and limited the readers' choice. Secondly, working manually, it is only possible to monitor the content of a limited number of law journals. This would have prompted readers to carefully select which journals they focused on. In this past landscape, 'where' you published determined how likely it was that your article would be read.

The contrast today is great indeed. Many, if not most, readers seek out the articles they read using search engines providing search results from a vast selection of journals, reviews and books. The need to be selective about what journals one looks at has all but vanished as the primary filtering method; we now have the tools to gather articles from a broad selection of journals and then select the articles that are best suited to our needs, not by the journal as a proxy, but by looking at the actual articles themselves amongst the top search results, which are guided by sophisticated algorithms assessing the relevance of the articles for the searches we have entered. In the light of this, all attempts at using the journal as a proxy for actual quality seem utterly misguided.

Some examples of the problems with the ABDC journal ranking list are illustrative. Looking at journals within the field of international law, it can be noted that, for example, both the Texas International Law Journal (ranked 17th amongst international law journals on the more established Washington and Lee list) and the Melbourne Journal of International Law (ranked 81st amongst international law journals on the Washington and Lee list) are included on the ranking list.16 Interestingly, both of

14 Ibid.

15 This is of course modified somewhat where there is arrangement for effective inter-library loans.

16 Washington and Lee University, Law Journals: Submissions and Ranking, 2006 - 2013 (2014)

Washington and Lee University Law Library <http://lawlib.wlu.edu/LJ/>. 
these journals were ranked ' $\mathrm{A}$ ', meaning that they are seen to be just below the highest level of journals.

The first problem with this is that those journals are no more oriented towards 'business' than are many other international law journals not included - journals generally held in higher regard. Similar concerns can be seen in other fields, such as information technology law where several well-known journals were not included. This fact alone seriously undermines the credibility of the ranking by bringing attention to its arbitrariness and lack of sophistication.

Secondly, the fact that the Melbourne Journal of International Law is ranked no less than 64 places below the Texas International Law Journal in the Washington and Lee list, while ranked on the same level in the ABDC Journal Quality list, highlights a tremendous diversity in result between different ranking initiatives. One may perhaps be tempted to point to the fact that the ABDC Journal Quality list is an Australian list, while the Washington and Lee list is American. However, such a geographically-founded explanation does not survive scrutiny. Other examples highlight considerable differences amongst Australian ranking initiatives. In the CALD/ERA ranking, the Griffith Law Review managed to undertake the impressive journey from being ranked ' $\mathrm{B}$ ' (the second lowest category) in the CALD draft ranking to being ranked ' $A$ "' (the highest category) in the final ERA version. In the sharpest contrast possible, in the ABDC Journal Quality list, the Griffith Law Review is ranked in the lowest category ' $\mathrm{C}$ '.

This shows us something important. Arguably, all ranking lists are flawed and/or corrupted by vested interests in the ranking process. Even if we were to accept that one journal ranking is indeed perfect, this would necessarily mean that all others are flawed, given that they otherwise would produce identical results, which they do not.

This takes us to the important lesson learnt from the journal ranking exercises discussed: in the context of journal rankings used to influence key aspects of academics' careers, close enough is not good enough. Indeed, given the tremendous impact journal ranking lists have for academic authors and for journals, close enough is seriously harmful because of the perverse incentives created by the ranking process when it is used as a proxy for quality.

We may here pause to also consider how the law journal publishers view the rankings. During an e-mail exchange with Senior Publisher Rhodri Jackson of Oxford University Press (OUP), he noted, 'my perspective (and OUP's) is that we cannot control the world and that we should concentrate on the things we can affect - i.e. 
producing a high quality journal. If we do that then by and large the rankings will take care of themselves'.17

Establishing just how widespread this way of thinking is amongst leading law journal publishers goes beyond the scope of this article. However, this refreshing perspective brings attention to several important matters. First of all, it suggests that at least one of the most established, and indeed prestigious, publishers is not overly concerned about how its journals are ranked under particular ranking schemes. This provides useful ammunition for those authors who do not necessarily target only top-ranked journals. And in fact, maybe this attitude - and the confidence shown in its products - is a stronger sign of quality than many indicators used in rankings; after all, at least amongst commercial publishers, only those that are confident in attracting top quality articles despite not being (highly) ranked will dare to disregard the ranking schemes. Secondly, as some major publishers of good standing may not go out of their way to ensure their journals are highly ranked, or even included, in various ranking schemes, only the better organised rankings will include such journals.

One consequence of the focus on highly ranked journals is a reduction in the emphasis on good text-book writing, and on journals addressed squarely at legal practitioners. These are the works that the student of law, the practitioner of law and the jurist turn to for guidance and, just occasionally, inspiration. Relying on ranking distracts legal scholars and law schools from a focus on serving this constituency.

Along the same lines, ranking exercises typically divert attention from specialist journals in favour of generalist journals. The reality is that we may all be familiar, and may indeed occasionally publish in, generalist journals. But if one writes on Japanese arbitration law, for example, one will rarely have reason to even be aware of specialist journals focused on completely different fields like European Internet law. Thus, when asking a diverse group of academics to rank journals, there is a strong tendency in favour of generalist journals.

Legal scholarship reaches its peak in the better legal texts. Our finest works of legal scholarship include the Corpus Juris Civilis, a concise and sophisticated codification of the ius civile (civil law), which was produced in 534AD by a team of legal scholars assembled by Justinian. This monumental work encapsulated the legal wisdom of the times. It included a textbook called the Institutes, which remains influential in the

17 E-mail from Rhodri Jackson to Dan Svantesson, 21 July 2014. (On file with authors; permission to reproduce this extract has been obtained from its author). 
civil law today. If textbooks were not viewed as 'research'18 in the science model, then Blackstone's Commentaries on the Laws of England would be assessed as equally unremarkable. Yet Blackstone's Commentaries - which were directed at students reached what many would see as the pinnacle of legal scholarship as they 'set out not only to formulate the rules of the common law, but to show their cohesion and to demonstrate that they were eminently reasonable and not just a heap of disconnected norms, produced by chance pronouncements in innumerable cases'. ${ }^{19} \mathrm{JE}$ Smith would value the work highly: '[Blackstone's] approach gave the law a coherence that it had lacked and imposed a system of rough order on what previously had been a hodgepodge of individual, unrelated, and often arcane precedents'. ${ }^{20}$ His contribution was that of a mighty pioneer and stories 'of itinerant [American] frontier judges carrying Blackstone in their saddlebags as their only written reference work may not be exaggerated'. ${ }^{21}$

The greatest work in corporate law, in English, came from Professor LCB Gower. In 1954, Gower published the first readable company law text, Principles of Modern Company Law.22 His engaging treatise surged above the detail and indifferent drafting of the first 100 years of corporate law statutes and cases. He conjured threads and themes that made sense of this relatively new field of law. He deftly described the

18 At least not for HERDC purposes.

19 RC Van Caenegem, Judges, Legislators and Professors: Chapters in European legal history (Cambridge University Press, 1987) 61-2; William Holdsworth also speaks generously of Blackstone: See William Holdsworth, Some Makers of English Law (Cambridge University Press, 1938) 240-7. Blackstone was variously an English parliamentarian, a judge of the Court of Common Pleas and an Oxford professor.

20 JE Smith, John Marshall: Definer of a Nation (Henry Holt and Company Inc, 1996) 77. Blackstone was in 1785 the first Vinerian Professor of English Law at Oxford. His four books were on The Rights of Persons, The Rights of Things, Private Wrongs and Public Wrongs.

21 Bruce Welling, Property In Things In the Common Law System (Scribblers Publishing, 1996) 62, n 45. Blackstone's texts appeared just before the American Revolution. They liked his books there because, among other things, he wrote that there should be no taxation without representation of those taxed. He had a greater effect in the US also because, for some time after the Revolution, English texts were scarce in the US. Incidentally, Bruce Welling's Corporate Law in Canada: The Governing Principles (Scribblers Publishing, 3rd ed, 2006) is arguably the finest successor to Gower: masterful, rigorous, insightful and attractivelywritten.

22 LCB Gower, Principles of Modern Company Law (Stevens \& Sons, $1^{\text {st }}$ ed, 1954). Palmer's Company Law (first published 1892) and Buckley on the Companies Acts (first published 1872), while widely read were not readable. They went by the ominous description 'practitioner texts'. 
fundamental principles of separate personality, limited liability and delegated management (directors and executives). Gower gave to corporate law its themes.

Such legal texts as these were the scholarly conduit of greatest influence. Why do we not value them - and their many, thoughtful, later editions - in our metrics such as HERDC? Why do we allow the value of our work to be distorted by a sciencedesigned, quantity-based, quality process?

If such works were subjected to today's one-size-fits-all metrics, would they even meet the criteria to be classed as 'research'? Would a High Court judge without an extensive record of publication in ' $A$ ' and ' $A$ "' journals inevitably be regarded as a less valuable scholar merely because he or she devoted a career on the bench to writing judgments, even though, by definition, those judgments made new law?

Law schools risk warping their scholarship and distracting themselves from the task of contributing to the evolution of the law if they tie themselves to rankings that pretend to precision and objectivity where there is little of either.

\section{THE PROPER ROLE OF LEGAL ACADEMICS AND LEGAL SCHOLARSHIP}

The focus on producing articles that conform to the expectations of highly-ranked journals turns legal academics away from the profession. Increasingly, legal academics are expected to adopt the methods of the social sciences which prize discovery, but often have little to say about application. There are a number of factors underlying this trend: one might be the fact universities and their research committees tend to be dominated by those with experience in the hard sciences and social sciences who, understandably enough, have limited understanding of the nature of legal education. Where this is so, legal academics and organisations such as CALD have a responsibility to protect the integrity of law as a discipline.

Another explanation may lie in the fact that contestable government funding was available for 'research projects' and PhD studies that emphasised the discovery of new knowledge. But comparatively little is 'discovered' in the law. Good lawyers and good legal scholars - have a different focus. They prize the development and exposition of knowledge, to be sure, but - as professionals - they see that process as being inextricably linked with application to real factual problems. As noted by Ronald Dworkin - the 2007 winner of the prestigious Holberg International Memorial Prize - sometimes described as the Nobel Prize equivalent for arts, humanities, social sciences, law and theology: 'Of course, law is a social phenomenon. But its 
complexity, function, and consequence all depend on one special feature of its structure. Legal practice, unlike many other social phenomena, is argumentative' ${ }^{23}$

Writing in 1990, Ernest Boyer attempted to redress the bias in favour of discovery by articulating a broader concept of scholarship. He split scholarship into four overlapping headings: the scholarship of discovery, the scholarship of integration, the scholarship of application and the scholarship of teaching. ${ }^{24}$ Boyer's work and its followers endeavoured to give teaching some of the regard that had been reserved for research, because teaching involves scholarship. Top teaching involves the skills, insights and revelations that characterise other types of scholarly work. '[T]eaching, at its best, shapes both research and practice'. ${ }^{25}$ Teaching is a form of scholarship.

Boyer's contribution is welcome, but it does not assist with the fundamental question: how do we assess the quality of legal scholarship, whatever form that scholarship takes? One aspect of this problem was neatly described by Richard Posner, a senior American judge and a professor at the University of Chicago (and a prolific scholar). He observed:

The result of the system of scholarly publication in law is that too many articles are too long, too dull, and too heavily annotated, and that many interdisciplinary articles are published that have no merit at all. Worse is the effect of these characteristics of law reviews in marginalizing the kind of legal scholarship that student editors can handle well - articles that criticize judicial decisions or, more constructively, discern new directions in law by careful analysis of decisions. Such articles are of great value to the profession, including its judicial branch, but they are becoming rare, in part because of the fascination of the legal academy with constitutional law, which in fact plays only a small role in the decisions of the lower courts. Law reviews do extensively analyze and criticize the constitutional decisions of the Supreme Court, but the profession, including the judiciary, would benefit from a reorientation of academic attention to lower-court decisions. Not that the Supreme Court isn't the most important court in the United States. But the 80 or so decisions that it renders every year get disproportionate attention compared to the many thousands of decisions rendered by other appellate courts that are much less frequently written about, especially since justices of the Supreme Court are the judges who are least likely to be influenced by critical academic reflection on their work..$^{26}$

23 Ronald Dworkin, Law's Empire (Hart Publishing Limited, 1998) 13.

24 Ernest Boyer, Scholarship Reconsidered: Priorities of the Professoriate (1990) The Carnegie Foundation 15-25 <https://depts.washington.edu/gs630/Spring/Boyer.pdf >.

25 Ibid.

26 Richard Posner, Against the Law Reviews (2004) Legal Affairs http://www.legalaffairs.org/ 
The challenge in Australia is arguably greater than that described by Posner. In this country, the legal academy has been particularly enthusiastic to promote interdisciplinary study in preference to 'traditional' legal scholarship. In doing so, the academy risks discounting the dynamic nature of legal scholarship, involving as it does a range of intellectual skills that are brought to bear on real problems.

In 1956, Benjamin Bloom ranked intellectual activity into six levels. ${ }^{27}$ He spoke of the skills of:

- evaluation (the most demanding);

- synthesis;

- analysis;

- application;

- comprehension; and

- knowledge (the least demanding).

Law reform and legal drafting work require intellectual skills of a high order - most obviously evaluation and synthesis. Legal studies and good law writing also tend to inhabit the analysis and synthesis levels, but legal scholarship is rarely isolated from the process of application. Almost all legal writing - authoring a text or article, preparing lectures, writing case comments and submissions and reports, commenting in the media, making panel presentations and conference writing - require a range of intellectual skills that ordinarily include application. Legal practitioners, for their part, tend to focus on the application level when dealing with complex legal work, which requires the ability to know what the law 'is' and then apply it to a completely new set of facts. It is a scholarly process that occurs every day in Australian law firms, barristers' chambers and hearing rooms. And good judges can do it all.

\section{IV 'IMPACT' AS A YARDSTICK OF SCHOLARLY QUALITY}

Debates about the nature of scholarship are intriguing, but they are perhaps ultimately unproductive. A more pragmatic approach to the task is required - one that attempts a broader view of the contribution that legal writing can make to the evolution of law, for any assessment of quality must inevitably be made with

issues/November-December-2004/review_posner_novdec04.msp>. See also Richard Posner, Law Reviews (2006) Chicago Unbound <http://chicagounbound.uchicago.edu/cgi/view content.cgi?article=2906\&context=journal_articles $>$.

27 Benjamin Bloom, Taxonomy of Educational Objectives (McKay, 1956). 
reference to the contribution or impact of the scholarship on the development of the law. The enquiry may ultimately be similar to the question of what makes a good judge. Richard Posner said the test for greatness in the work of judges is the contribution that the decisions make to the development of legal rules and principles'. ${ }^{28}$ Exhibited in the work of aptly-named Judge Learned Hand was 'the gift of verbal facility that enables a familiar proposition to be expressed memorably, arrestingly, thus enforcing attention, facilitating comprehension, and, often, stimulating new thought. ${ }^{29}$

Lord Denning fits the criteria. So does Lord Wilberforce; Murray Gleeson and Michael Kirby are modern Australian nominees. But perhaps the leading contender is Sir Owen Dixon. Renowned company lawyer HAJ Ford said of Dixon:

If one seeks to identify what it was in his judgments that gave him such a high reputation in the common law world it is the conjunction of a mastery of common law principle ... a scholarly inclination, a sense of the worth of history..$^{30}$

George Winterton looked for 'depth' when commenting on Australian Chief Justices: 'Barwick was once described as "very clever, but not deep"'. He lacked the breadth of vision and depth of principle to leave a permanent judicial legacy in the class of Griffith, Isaacs or Dixon'. ${ }^{31}$ At any rate, the scholarship involved in judges writing judgments seems beyond intelligent dispute. This may be seen as yet another distinguishing characteristic for the field of law and the use of 'impact', for example, as a yardstick may usefully be adopted more widely also in assessing the quality of legal academic work. This is not to say that all judgments are well written.

Thus, rather than looking to the social sciences - or even more inappropriately, the natural sciences - for guidance on what constitutes good scholarship, the legal academy should be looking back to the profession from which it is becoming increasingly detached. Ultimately, legal scholarship is more helpfully seen as an extension of the central function of all lawyers, including judges; we are all engaged in acts of advocacy, the ultimate aim of which is to persuade through a process of argument. Approaching legal scholarship in this way helps to re-engage that

28 Richard Posner, 'The Learned Hand Biography and the Question of Judicial Greatness' (1994) 104 Yale Law Journal 511, 523-4.

29 Ibid.

30 HAJ Ford, 'Sir Owen Dixon: His Judgments in Private Law' (1986) 15 Melbourne University Law Review 582, 590.

31 George Winterton, 'Barwick the Judge' (1998) 21 University of New South Wales Law Journal 109, 116. 
dimension of professional work, which is at risk of being lost from the modern legal academy - the dynamic process of applying knowledge to resolve problems.

Scholarship in law being more accurately described as 'acts of advocacy' has several important implications. For example, the law teacher is involved in this scholarship or advocacy as she explains existing law and, working from principle, predicts the course of the law. Lawyers are engaged in a pure process of advocacy, rather than in scholarship, as we go from general knowledge about the existing law to specific applications of that vast knowledge in a scholarly fashion. We are engaged in a pure process of advocacy working with statutes and previous factual situations (reported cases), although lawyers and law teachers can and do invent hypotheticals or problems to simulate this process. This is what the law reformers do, too. They take the existing laws and then propel themselves forward, sometimes into the abyss, to predict the best legislative solutions to the legal problems and challenges of the future. Then they draft laws that anticipate future problems and provide solutions in advance. This, too, is a pure act of scholarship.

\section{NEW WAYS OF ASSESSING LEGAL SCHOLARSHIP}

The Commonwealth government is considering changes to higher education funding arrangements that would see public universities permitted to charge fees. Such changes would produce a wide variation in the range of fees that are charged, with the older, more established universities ('the sandstones') almost certainly in a position to charge a higher premium for some courses, including law.

It is likely universities will come to rely on tuition revenue derived directly from students for an increasingly large part of their income. That has important implications for the way in which those institutions are marketed and run, and for legal scholarship. One can expect a greater institutional emphasis on activities that attract fee-paying students to the university. Since those fee paying students are likely to be attracted to institutions that enjoy a reputation for producing graduates that are sought after by employers, it seems inevitable that university law schools are bound to focus more attention on servicing the needs of those employers.

This employer focus will exert a gravitational pull on legal scholarship. The value of research grants are a fraction of the amounts that will be derived from tuition. Institutions are likely to value and support scholarship that the profession wants traditional legal scholarship like that which Richard Posner described; in other words, scholarship that is assessed according to more pragmatic standards than the metrics employed by the rankers of legal journals.

This is no bad thing. Law schools and their academics can be left to get on with superior professional education that values advocacy, while leaving social science 
research to the social scientists - for lawyers are not social scientists any more than they are scientists. Using science's tools and science analogies for assessment of research competence in law is singularly inappropriate. One size emphatically does not fit all. How the discipline of law came supinely to accept a science model for measuring quality of law scholarship is an abiding mystery.

\section{IN CONCLUSION}

The preceding arguments have no doubt conveyed our disliking of rankings. Yet, despite their corruptibility and habitual negative impact, we recognise that people must be free to rank to their heart's content. The bigger question is what the rankings are used for and here the responsibility falls broader. Deans concerned with the welfare and long-term success of the faculties they work for must have the bravery to look beyond infertile, bureaucratic, and ultimately unjust, proxies for quality in guiding their colleagues' scholarly efforts.

And of course, rankings are not the only problematic proxy for quality. There is a growing overconfidence in citation counts as a proxy for impact. This is as problematic as journal ranking is. It is not uncommon for articles to be cited for their extremist or quirky points of view. In arguing that the law does not apply to conduct on the Internet, Johnson and Post cemented their place in history in that their article ranks amongst the most cited ever journal articles. ${ }^{32}$ It is so frequently cited because so few people agree with it. Being extremist and controversial is hardly the hallmark of great legal scholarship.

Perhaps the most fruitful perspective from which one may approach the questions dealt with above is to look at them from the perspective of a junior academic within a specialist legal field wishing to progress her career. What advice would you give when she asks you where she should publish her work?

For most specialist fields there are few if any highly ranked journals in the discredited, but still widely used, old ERA ranking list. ${ }^{33}$ Thus, if your advice is that she ought to publish in the specialist, or practitioner-oriented, journals that her target audience reads you risk exposing her to the scorn of those peers who equate their own unfamiliarity with specialist journals with those journals being inferior to the more widely-known generalist journals. The alternative is to encourage her to

32 Fred R Shapiro and Michelle Pearse, 'The Most-Cited Law Review Articles of All Time' (2011-2012) 110 Michigan Law Review 1483, 1494.

33 Dan Svantesson, 'Truisms about the Australian Publishing Climate for Law Journal Articles, and Some Strategies to Cope; or "A Feminist Perspective on the Human Rights of Vegetarian Child-Soldiers in Outer Space"' (2011) 10(3) Canberra Law Review 4, 4-29. 
publish in widely-known generalist journals, the better to appease the slaves of rankings. However, that will of course come at the price of a loss in influence, because such journals are not widely read amongst specialist and practitioner audiences.

Just as one combats discrimination by preferring a highly skilled person with a minority heritage over an unskilled worker of the dominant heritage, so too, in the case of where to publish, we must challenge irrational and outdated methods and eschew unfair biases. We urge the current generation of legal academics to vanquish the flawed habits of journal ranking and forum pomposity and identify and pursue what is truly valuable research and scholarship in law.

We have sought to illuminate an alternative direction law schools may take; an alternative that recognises that the discipline of law is unique and should not be so easily led astray by the metrics, rankings and citation indexes so willingly adopted by the natural sciences and to a degree by the social sciences. We can, and must, do better than that.

Legal writing is an intellectually demanding activity. The peak scholarly achievement in law is the writing of the comprehensive legal text, which identifies and develops themes in the law. Insightful and comprehensive legal judgments meet these criteria, as do leading legal articles on themes and developments in the law. The forum or publisher or prolixity of these publications does not determine their quality. We endorse van Gestel's suggestion:

What we need in order to fuel a serious debate on quality of both legal education and scholarship is more information with regard to what legal scholars themselves consider important for the quality of teaching and research, also from a more substantive perspective. ${ }^{34}$

34 Rob van Gestel, above n 8, 172. 